Response to Maru et al. 2012. "A Synthesis of Current Approaches to Traps Is Useful But Needs Rethinking for Indigenous Disadvantage and Poverty Research"

\title{
Adaptive Capacity as Cultural Practice
}

\author{
Benedict J. Colombi ${ }^{1}$ and Courtland L. Smith ${ }^{2}$
}

Key Words: adaptability; adaptive capacity; Grand Ronde Tribe; resilience thinking; transformability

Maru et al. (2012) provide an insightful synthesis about the poverty and rigidity traps. They note how these states can be quite resilient and undesirable for indigenous cultures. We support their approach and add three additional considerations. (1) Maru et al. (2012) tend to interchange adaptive capacity and resilience as concepts. Adaptive capacity and resilience have two different purposes. Resilience is a state or condition. Adaptive capacity is the ability to change one's state, or condition. (2) Indigenous culture narratives and experience are a good source of long-term data for generating hypotheses about adaptive capacity as a cultural process. (3) Escaping the poverty trap may require cultural processes that are adaptive and transformative. Indigenous people adapting sovereign power in an ecosystem may also include transformative portfolios of economic activity; new leadership, vision, and partnerships to work within and between groups; and adapting their values and knowledge to new situations.

\section{Adaptive capacity}

Adaptive capacity is central to discussions of resilience thinking (Folke et al. 2010). Maru et al. (2012) provide an excellent review of the literature, where they emphasize that poverty and rigidity traps result from the "...configurations of the levels of the three fundamental variables: potential, connectedness, and adaptive capacity." In adaptive cycle diagrams, "resilience," not "adaptive capacity" is the third axis. Holling et al. (2002) and Holling and Gunderson (2002) discuss resilience as a variable that explains a condition of social-ecological systems. In the raft example (Holling et al. 2002), the fate of the raft is the result of social and political structure. Adaptation and transformation are identified by Folke et al. (2010) as seemingly "counterintuitive" processes to learn about and influence resilience, as well as the capacity to change trajectories and cross thresholds. Through the processes of adaptability and transformability, adaptive capacity is a cultural process to achieve resilience.

The Resilience Alliance (2002) points to Folke et al. (2002) and four critical factors associated with adaptive capacity. These factors interact across temporal and spatial scales and are important for dealing with natural resource dynamics during periods of release and reorganization-learning to live with change and uncertainty; nurturing diversity for resilience; combining different types of knowledge for learning; and creating opportunity for self-organization towards socialecological sustainability.

Recent issues of Ecology and Society include numerous references to adaptive capacity. For example, Cabell and Oelofse (2012) link adaptive capacity with social and cultural capital in an effort to find "behaviors that, when present, imply that the system is more capable of persisting." Education and social learning are keys to adaptive capacity in Wamsler et al. (2012) and McCarthy et al. (2011). Developing adaptive capacity in situations of climate change, van de Sand (2012) explains how in the context of vulnerability, payments for ecosystem services (PES) can be pro-poor and pro-adaptation by improving health and well-being outcomes.

Adaptive capacity is discussed in other areas. USAID (2009: $\mathrm{xv)}$ emphasizes cultural dimensions in its definition, "Adaptive capacity depends on economic well-being, ecological well-being, the extent of dependency on natural resources, infrastructure (human-built or natural), effectiveness of institutions and governance systems, insurance, secure land tenure and mediation measures, and information and communication systems. A community with the capacity to adapt is likely to be more resistant to impacts or able to recover from stressful events and conditions."

Adger et al. (2007: 727), focusing on climate change, also point to the importance of cultural dimensions in adaptive capacity. They note there are " many examples where social capital, social networks, values, perceptions, customs, traditions and levels of cognition affect the capability of communities to adapt to risks related to climate change." Adaptive capacity is also part of the Intergovernmental Panel on Climate Change (Brooks et al. 2005, Parry et al. 2007), UN Food and Agricultural Organization (FAO 2006), The World Bank (2010), The World Resources Institute (2009), United Nations Development Programme (UNDP 2005), and other organization's dealing with social-ecological system dynamics.

Maru et al. (2012) discuss various forms of capital for escaping the poverty trap-human, financial, physical, and natural. Capital is discussed in association with the potential axis of

${ }^{1}$ University of Arizona, ${ }^{2}$ Oregon State University 
Table 1. Comparisons of adaptive capacity elements with dimensions of culture from a selection of sources.

\begin{tabular}{|c|c|c|c|}
\hline Dimensions of Culture & Economy \& Ecology & Society \& Polity & Ideology \& Knowledge \\
\hline Colombi (2012a) & make & do & think \\
\hline Bodley (2005) & material & behavioral & mental \\
\hline Harris (1979) & infrastructure & structure & superstructure \\
\hline Resilience Alliance (Folke 2002 et al.) & nurturing diversity for resilience & $\begin{array}{l}\text { creating opportunity for self- } \\
\text { organization towards social- } \\
\text { ecological sustainability }\end{array}$ & $\begin{array}{l}\text { learning to live with change and } \\
\text { uncertainty; combining different } \\
\text { types of knowledge for learning }\end{array}$ \\
\hline USAID (2009:xv) & $\begin{array}{l}\text { natural resources, infrastructure } \\
\text { (human-built or natural), secure land } \\
\text { tenure }\end{array}$ & $\begin{array}{l}\text { effectiveness of institutions and } \\
\text { governance systems, insurance, and } \\
\text { mediation measures }\end{array}$ & $\begin{array}{l}\text { information and communication } \\
\text { systems }\end{array}$ \\
\hline Adger et al. (2007:727) & $\begin{array}{l}\text { economic development and } \\
\text { technology }\end{array}$ & $\begin{array}{l}\text { social capital, social networks, } \\
\text { governance structures }\end{array}$ & $\begin{array}{l}\text { human capital, values, perceptions, } \\
\text { customs, traditions and levels of } \\
\text { cognition }\end{array}$ \\
\hline Capital (Costanza et al. 1997) & natural, built & social & human \\
\hline
\end{tabular}

the adaptive cycle. Social capital as a component of adaptive capacity is suggested by Pelling and High (2005). Vemuri and Costanza (2006) use natural, built, social, and human capital to measure life satisfaction.

Adaptations and maladaptations occur in human history. Indigenous cultures provide examples of success in using their adaptive capacity for both resilience and failure to reorganize in the back loop of the adaptive cycle. In Table 1, adaptive capacity is framed as a cultural construct. The dimensions of culture are commonly characterized by economy and ecology, society and polity, and ideology and knowledge. An easy to remember cultural framing is to make, do, and think (Colombi 2012a). In Table 1, the top three rows give social science dimensions of culture from Colombi (2012a), Bodley (2005), and Harris (1979). Mapped onto the three cultural dimensions are the Resilience Alliance, USAID, climate change, and capital elements from the adaptive capacity discussion highlighted above.

\section{An indigenous narrative}

An example of adaptive capacity to escape the poverty trap using these cultural dimensions is the Grand Ronde tribe of Oregon (Table 2). Given space limitations, the adaptive and transformative elements of Grand Ronde adaptive capacity can only be sketched in general terms. The Grand Ronde tell their own story (CTGR 2011), which we paraphrase as a narrative on adaptive capacity in the face of tremendous internal and external change. Before treaties with the United States in the 1850s, the 26 tribes and bands that became The Confederated Tribes of Grand Ronde lived in the area west of the Cascade Mountains from northern California to the
Columbia River in the northwest US. This is an area of 65,000 $\mathrm{km}^{2}$. These tribes had an aquatic and terrestrial portfolio of salmon, skakwal (eels), mammals, camas, wapato, hazelnuts, acorns, and huckleberries.

Many external factors led to impoverishment of the Grand Ronde. Explorers brought diseases after 1770 that led to $90 \%$ population declines by the mid $-19^{\text {th }}$ century (Boyd 1999). The US made treaties with Pacific Northwest tribes promised food, clothing, household supplies, schools, agricultural implements and training, and other items to enable survival in exchange for tribal lands that were given to nontribal settlers. Most US government promises were not kept. Between 1853-1855, Willamette Valley tribes, and those south to Shasta, signed treaties, and in 1856, 2000 survivors moved to the Grand Ronde reservation-an area to of just over $280 \mathrm{~km}^{2}$. The treaties also reserved certain rights. One commonly included was, "The right of taking fish at all usual and accustomed grounds and stations is further secured to said Indians in common with all citizens of the United States (Cohen 1986: 38). This promise has become a central theme in the exercise of Pacific Northwest tribal sovereignty.

During the late $19^{\text {th }}$ century, Congress reduced the size of reservations arguing that due to population declines the original size was no longer needed. The Dawes Act (1887) allotted tribal lands with the objective of making American Indians farmers. The effects of the Dawes Act were reversed by the Tribal Reorganization Act (1934). Termination became federal policy from the mid-1940s to the mid-1960s.

About 1970, the Grand Ronde faced their greatest poverty and depended on small farms and low-wage logging, farm labor, 
Table 2. Comparisons of adaptive capacity elements with dimensions of Grand Ronde culture through adaptive cycle states from narrative sources.

\begin{tabular}{llll}
\hline \hline Adaptive Cycle States & Economy \& Ecology & Society \& Polity & Ideology \& Knowledge \\
\hline $\begin{array}{l}\text { Grand Ronde: precontact - living in } \\
\text { the conservation phase. }\end{array}$ & $\begin{array}{l}\text { portfolio of aquatic \& terrestrial } \\
\text { resources and sovereignty over these } \\
\text { territories }\end{array}$ & $\begin{array}{l}\text { 26 tribes operating as independent } \\
\text { units with their own social and } \\
\text { governance systems }\end{array}$ & $\begin{array}{l}\text { believing themselves to be part of } \\
\text { natural systems }\end{array}$ \\
$\begin{array}{l}\text { Grand Ronde: reservation- } \\
\text { experiencing release and } \\
\text { reorganization }\end{array}$ & $\begin{array}{l}\text { individual income as small farmers } \\
\text { and low-wage, logging, and farm } \\
\text { labor jobs. }\end{array}$ & $\begin{array}{l}\text { emergency of tribal social } \\
\text { organization and governance }\end{array}$ & $\begin{array}{l}\text { dominant culture devaluing of their } \\
\text { cultural ideas \& knowledge }\end{array}$ \\
$\begin{array}{l}\text { Grand Ronde: restoration- } \\
\text { exploitation and conservation }\end{array}$ & $\begin{array}{l}\text { casino on sovereign lands and } \\
\text { diversification of economic portfolio }\end{array}$ & $\begin{array}{l}\text { more formalized tribal governance } \\
\text { and polity }\end{array}$ & $\begin{array}{l}\text { creation of synthetic language \& } \\
\text { culture }\end{array}$ \\
Narrative synthesis & $\begin{array}{l}\text { sovereignty over ecological } \\
\text { opportunities and creation of } \\
\text { economic portfolios }\end{array}$ & $\begin{array}{l}\text { leadership, vision and partnerships } \\
\text { to affect actions within and between } \\
\text { groups }\end{array}$ & $\begin{array}{l}\text { ecological knowledge and the values } \\
\text { to apply that knowledge }\end{array}$ \\
\hline
\end{tabular}

and service jobs. The reservation was down to a storage shed and cemetery on $0.02 \mathrm{~km}^{2}$. After 1972, several leaders emerged with a transformative vision to restore the Grand Ronde lands, society, and culture (CTGR 2011). In 1983, the tribe won its restoration and received $40 \mathrm{~km}^{2}$ of land in 1988. In 2012, the Grand Ronde have $50 \mathrm{~km}^{2}$ and casino, forest lands, firefighting, and craft revenues.

In their first precontact state of existence, the Grand Ronde were gathers, fishers, and hunters. Next, the coming of outsiders convert them to the reservation state, where they participated in a wage economy as farmers, farm workers, and loggers. During this second state they plunged deepest into the poverty trap. The third, restoration state, is anchored in transforming their legal status, adapting their sovereignty, getting returned land, and transforming to a new and more tribally controlled economic portfolio.

\section{Adaptive and transformative processes}

The Grand Ronde narrative history supports the endurance of the poverty trap that Maru et al. (2012) note is common to many indigenous cultures. The Grand Ronde, however, pursued a process for escaping the poverty trap. Transformations in US public policy, along with the Grand Ronde culture's adaptive and transformative capacity came together. Granting American Indian cultures the option of using casino revenues to diversify their economic portfolio was a key part of the process. The Grand Ronde adapted their sovereignty preserved in treaties and transformed their economic portfolio to develop new opportunities (Table 2).

Sovereignty typically means having a property right to a resource. Most often, this is a land base, but it could also be a fishing or hunting quota, mineral or water rights, access to economic activities open to tribal groups, or ownership of intellectual property. The Economics Resource Group, Inc. (1998) commented on the importance of sovereignty, "Tribes that establish their own decision-making power over resources and take control of their economic destinies are better off than tribes that accede to outsiders' decisions, goals, plans, or programs." A portfolio consists to multiple economic activities and sovereignty enables a group to transform its economy.

The primary society and polity tools for Grand Ronde are leadership, vision, and partnerships (Table 2). Leadership comes from tribal leaders with a vision about the tribe's future in the new context of casino gambling. The Grand Ronde used their sovereignty to transform their economy and adapting it to available opportunities where they could exercise a competitive advantage. Revenues from their casino facilitate partnerships and public awareness of tribal values and culture.

Most interesting about the tribe is how members adapted their ideology and identity out of many different linguistic and cultural heritages to become the Grand Ronde, whose language is Chinuk Wana (CTGR 2011). They built on their values and knowledge about their relations with nature to protect and use natural resources. The Grand Ronde are partners with many nontribal organizations in salmon and natural resource restoration.

The Grand Ronde example suggests adaptability (influencing system resilience) and transformability (creating new systems) are key concepts related to resilience thinking as suggested by Folke et al. (2010). Three factors for achieving resilience seem important. First, resilience thinking needs to continue the path started by Holling (1973) and recognize the dynamics of social-ecological systems beyond the ball and basin analogy. Hurricane Katrina, the Fukushima Daiichi 
nuclear disaster, patterns of climate change, and the Grand Ronde are examples of natural and social disturbance combining to exacerbate the effects of either one. The idea of stability zones is increasingly less the norm for socialecological systems where natural and social disturbances combine to make these systems dynamic and their futures hard to predict. The Grand Ronde are one culture in a complex system of cultures that operate in continual natural and social disturbance. Developing cultural strategies to live in dynamic and continually changing systems may be more a concern for resilience than finding and returning to stability domains.

Second, because of the continuing dynamic change in socialecological systems, the Grand Ronde illustrate how both adaptability and transformability are part of adaptive capacity. The Grand Ronde exhibit both adaptive capacity in their adaptability to persist as a culture and in their transformability to adopt new trajectories and cross thresholds. They adapted their values and language while also transforming their economy and institutions to persist in each of the three states they have experienced, finally getting an increase in selfcontrol during the third state. The Grand Ronde's ability to adapt and transform to external forces enabled their persistence as a culture. Many cultures have died out due to continuing internal and external disturbance. The Grand Ronde survived by turning dynamic change into tribal opportunity.

Third the Grand Ronde can be seen as an example of what Folke et al. (2010) call "specific resilience." The Grand Ronde are one culture in a very complex system of interacting cultures. In the third state, the restoration and recognition of Grand Ronde sovereignty gave them a voice in regional restoration planning and action. In this sense, they contribute to a broader, more general regional resilience, which has a complex set of regional actors. For example, the tribes suggest that supplementation facilities work better than hatcheries to increase abundance and re-establish fish runs (Galbreath 2011). The tribes, then, used their cultural knowledge to design facilities and programs that restore salmon and steelhead runs in an effort to reverse long-term decline. Similar use of tribal knowledge has been shown to offer insights to nontribal science and policy elsewhere in the Pacific Northwest (Langdon 2006, 2007, Menzies 2010, 2012, Colombi 2012b, Diver 2012). As tribal ideas about ecological values, restoration practices, and environmental protection prove valuable, the Grand Ronde along with other tribes contribute to general resilience in the region.

Progress on understanding the elements of adaptive capacity requires more study, discussion, and synthesis of cultural concepts and processes. Historical narratives can offer insights into the important variables, relations, and processes to use in discussing adaptive capacity. Historical examples can provide insights of how cultures get caught in and escape from the poverty and rigidity traps, how adaptability and transformability interact, and how experiences transcend scales. Narratives will not provide the empirical approaches in figures 3 and 4 in Maru et al. (2012), but they can identify variables to include and hypotheses to test. Taking a cultural perspective to adaptive capacity, let hypotheses encompass the economic and ecological, social and political, and ideology and knowledge that cultures develop to be flexible, adaptive, continually learning, and transforming when facing changing and unknown futures. Ecology and economy encompasses portfolios that allow substitution and shifting between activities to deal with variability (Chapin et al. 2009, Cinner et al. 2009). Sovereignty is critical to control of resources and establish rights to engage in an activity limited to sovereigns (Hill et al. 2012). The society and polity dimension has leadership that increases vision and trust to complement partnerships that achieve adaptive capacity (Folke et al. 2005, Smith and Stirling 2010). Ideology and knowledge provided the basis for action. Adaptive capacity comes from ideology, knowledge, learning, recognizing, and engaging in new activities (Olsson et al. 2004, Diver 2012). These cultural dimensions of adaptive capacity build potential, connectedness, and resilience using the processes of adaptability and transformability.

Responses to this article can be read online at: http://www.ecologyandsociety.org/issues/responses. $\mathrm{php} / 5242$

\section{LITERATURE CITED}

Adger, W. N., S. Agrawala, M. Q. Mirza, C. Conde, K. O'Brien, J. Pulhin, R. Pulwarty, B. Smit, and K. Takahashi. 2007. Assessment of adaptation practices, options, constraints and capacity. Pages 717-743 in M. L. Parry, O. F. Canziani, J. P. Palutikof, P. J. van der Linden and C. E. Hanson, editors. Contribution of Working Group II to the Fourth Assessment Report of the Intergovernmental Panel on Climate Change. Climate change 2007: impacts, adaptation and vulnerability. Cambridge University Press, Cambridge, UK. [online] URL: http://www.ipcc-wg2.gov/AR4/website/fi.pdf

Bodley, J. H. 2005. Cultural anthropology: tribes, states, and the global system. McGraw Hill, Boston, Massachusetts, USA.

Boyd, R. T. 1999. The coming of the spirit of pestilence: introduced infectious diseases and population decline among Northwest Coast Indians, 1774-1874. University of Washington Press, Seattle, Washington, USA.

Brooks, N., W. N. Adger, and P. M. Kelly. 2005. The determinants of vulnerability and adaptive capacity at the 
national level and the implications for adaptation. Global Environmental Change 15(2):151-163. http://dx.doi.org/10.1016/ j.gloenvcha.2004.12.006

Cabell, J. F., and M. Oelofse. 2012. An indicator framework for assessing agroecosystem resilience. Ecology and Society 17(1): 18. http://dx.doi.org/10.5751/ES-04666-170118

Chapin, F.S., III., Folke, C., Kofinas, G. P. 2009. A framework for understanding change. Pages 3-28 in F.S. Chapin III, G.P. Kofinas, and C. Folke, editors. Principles of ecosystem stewardship: resilience-based natural resource management in a changing world. Springer Verlag, New York, USA. http:// dx.doi.org/10.1007/978-0-387-73033-2_1

Cohen, F. G. 1986. Treaties on trial: the continuing controversy over Northwest Indian fishing rights. University of Washington Press, Seattle, Washington, USA.

Colombi, B. J. 2012a. Salmon and the adaptive capacity of Nimiipuu (Nez Perce) culture to cope with change. American Indian Quarterly 36(1): 75-97.

Colombi, B. J. 2012b. 'Salmon and his people': encounters with global capitalism. Pages 183-206 in B. J. Colombi and J. F. Brooks, editors. Keystone nations: indigenous peoples and salmon across the North Pacific. School for Advanced Research Press, Santa Fe, New Mexico, USA.

Costanza, R., R. d'Arge, R. de Groot, S. Farber, M. Grasso, B. Hannon, K. Limburg, S. Naeem, R. V. O'Neill, J. Paruelo, R. G. Raskin, P. Sutton, and M. van den Belt. 1997. The value of the world's ecosystem services and natural capital. Nature 387:253-260. http://dx.doi.org/10.1038/387253a0

Cinner, J., M. M. P. B. Fuentes, and H. Randriamahazo. 2009. Exploring social resilience in Madagascar's marine protected areas. Ecology and Society 14(1): 41. [online] URL: http:// www.ecologyandsociety.org/vol14/iss1/art41/

Confederated Tribes of Grand Ronde (CTGR). 2011. Ntsayka Ikanum: our story. Grand Ronde, Oregon, USA. [online] URL: http://www.grandronde.org/ikanum/index.html

Dawes Act, Act of Feb. 8, 1887 (24 Stat. 388, ch. 119, 25 USCA 331), Acts of Forty-ninth Congress-Second Session, 1887.

Diver, S. 2012. Columbia river tribal fisheries: life history stages of a co-management institution. Pages 207-235 in B. J. Colombi and J. F. Brooks, editors. Keystone nations: indigenous peoples and salmon across the North Pacific. School for Advanced Research Press, Santa Fe, New Mexico, USA.

The Economics Resource Group, Inc. 1998. American Indian gaming policy and its socio-economic effects: a report to the National Gambling Impact Study Commission. Cambridge,
Massachusetts, USA. [online] URL: http://www.indiangaming. org/library/studies/1004-erg 98rept to ngisc.pdf.

Food and Agriculture Organization of the United Nations (FAO). 2006. Building adaptive capacity to climate change: policies to sustain livelihoods and fisheries. New directions in fisheries: a series of policy briefs on development issues, No. 08. Rome, Italy. [online] URL: http://ftp.fao.org/docrep/ fao/010/a1115e/a1115e00.pdf

Folke, C., S. R. Carpenter, B. Walker, M. Scheffer, T. Chapin, and J. Rockström. 2010. Resilience thinking: integrating resilience, adaptability and transformability. Ecology and Society 15(4): 20. [online] URL: http://www.ecologyandsociety. org/vol15/iss4/art20/

Folke C., J. Colding, and F. Berkes. 2002. Synthesis: building resilience for and adaptive capacity in social-ecological systems. Pages 352-383 in F. Berkes, J. Colding, and C. Folke, editors. Navigating social-ecological systems: building resilience for complexity and change. Cambridge University Press, Cambridge, UK. http://dx.doi.org/10.1017/ CBO9780511541957.020

Folke, C., T. Hahn, P. Olsson, and J. Norberg. 2005. Adaptive governance of social-ecological systems. Annual Review of Environment and Resources 30:441-473. http://dx.doi. org/10.1146/annurev.energy.30.050504.144511

Galbreath, P. 2011. Critique of the prevailing scientific paradigm: the tribal perspective of hatchery/wild relative fitness and relative reproductive success results. [online] URL: http://www.critfc.org/vision_conf/presentations/galbreath.pdf

Harris, M. 1979. Cultural materialism: the struggle for a science of culture. Random House, New York, New York, USA.

Hill, R., C. Grant, M. George, C. Robinson, S. Jackson, and N. Abel. 2012. A typology of indigenous engagement in Australian environmental management: implications for knowledge integration and social-ecological system sustainability. Ecology and Society 17(1): 23. http://dx.doi. org/10.5751/ES-04587-170123

Holling, C. S. 1973. Resilience and stability of ecological systems. Annual Review of Ecology and Systematics 4:1-23. http://dx.doi.org/10.1146/annurev.es.04.110173.000245

Holling, C. S. and L. H. Gunderson. 2002. Resilience and adaptive cycles. Pages 25-62 in L. H. Gunderson and C. S. Holling, editors. Panarchy: understanding transformations in human and natural systems. Island Press, Washington, D.C., USA. 
Holling, C. S., L. H. Gunderson, and D. Ludwig. 2002. In quest of a theory of adaptive change. Pages 3-22 in L. H. Gunderson and C. S. Holling, editors. Panarchy: understanding transformations in human and natural systems. Island Press, Washington, D.C., USA.

The Indian Reorganization Act (Wheeler-Howard Act) June 18, 1934. (P.L. 73-383) U.S. Congress.

Langdon, S. J. 2006. Tidal pulse fishing. Pages 21-46 in C. Menzies, editor. Traditional ecological knowledge and resource management. University of Nebraska Press. Lincoln, Nebraska. USA.

Langdon, S. J. 2007. Sustaining a relationship. Pages 233-273 in M. E. Harkin and D. R. Lewis, editors. Native Americans and the environment: perspectives on the ecological Indian. University of Nebraska Press. Lincoln, Nebraska, USA.

Maru, Y. T., C. S. Fletcher, and V. H. Chewings. 2012. A synthesis of current approaches to traps is useful but needs rethinking for indigenous disadvantage and poverty research. Ecology and Society 17(2): 7. http://dx.doi.org/10.5751/ ES-04793-170207

McCarthy, D. D. P., D. D. Crandall, G. S. Whitelaw, Z. General, and L. J. S. Tsuji. 2011. A critical systems approach to social learning: building adaptive capacity in social, ecological, epistemological (SEE) systems. Ecology and Society 16(3): 18. http://dx.doi.org/10.5751/ES-04255-160318

Menzies, C. R. 2010, Dm sibilhaa'nm da laxyuubm Gitxaala: picking abalone in Gitxaala territory. Human Organization 69 (3): 213-220.

Menzies, C. R. 2012. The disturbed environment: The indigenous cultivation of salmon. Pages 161-182 in B. J. Colombi and J. F. Brooks, editors. Keystone nations: indigenous peoples and salmon across the North Pacific. School for Advanced Research Press, Santa Fe, New Mexico, USA.

Olsson, P., C. Folke, and T. Hahn. 2004. Social-ecological transformation for ecosystem management: the development of adaptive co-management of a wetland landscape in southern Sweden. Ecology and Society 9(4): 2. [online] URL: http:// www.ecologyandsociety.org/vol9/iss4/art2/

Parry, M. L., O. F. Canziani, J. P. Palutikof, P. J. van der Linden, and C. E. Hanson. 2007. Climate change 2007: impacts, adaptation and vulnerability. Contribution of Working Group II to the Fourth Assessment Report of the Intergovernmental Panel on Climate Change, Cambridge University Press Cambridge, UK. [online] URL: http://www. ipcc-wg2.gov/AR4/website/fi.pdf.
Pelling, M. and C. High. 2005. Understanding adaptation: what can social capital offer assessments of adaptive capacity? Global Environmental Change 15(4):308-319. http://dx.doi. org/10.1016/j.gloenvcha.2005.02.001

Smith, A., and A. Stirling. 2010. The politics of socialecological resilience and sustainable socio-technical transitions. Ecology and Society 15(1): 11. [online] URL: http://www.ecologyandsociety.org/vol15/iss1/art11/

Resilience Alliance. 2002. Adaptive capacity. [online] URL: http://www.resalliance.org/565.php.

United Nations Development Programme (UNDP). 2005. Adaptation definitions and levels. [online] URL: http://www. undp.org/climatechange/adapt/definitions.html.

United States Agency for International Development (USAID). 2009. Adapting to coastal climate change: a guidebook for development planners. [online] URL: http:// www.crc.uri.edu/download/CoastalAdaptationGuide.pdf.

van de Sand, I. 2012. Payments for ecosystem services in the context of adaptation to climate change. Ecology and Society 17(1): 11. http://dx.doi.org/10.5751/ES-04561-170111

Vemuri, A. W. and R. Costanza. 2006. The role of human, social, built, and natural capital in explaining life satisfaction at the country level: toward a national well-being index (NWI). Ecological Economics 58:119-133. http://dx.doi.org/10.1016/ j.ecolecon.2005.02.008

Wamsler, C., E. Brink, and O. Rentala. 2012. Climate change, adaptation, and formal education: the role of schooling for increasing societies' adaptive capacities in El Salvador and Basil. Ecology and Society 17(2): 2. http://dx.doi.org/10.5751/ ES-04645-170202

World Bank. 2010. Adaptation guidance notes, key words and definitions. [online] URL: http://climatechange.worldbank. org/climatechange/content/adaptation-guidance-notes-key-wordsand-definitions

World Resources Institute. 2009. The National Adaptive Capacity Framework: Key Institutional Functions for a Changing Climate. Pilot Draft. World Resources Institute. Washington, DC, USA. 